OPEN ACCESS

Edited by:

James Cotner,

University of Minnesota, USA

Reviewed by:

Guang Gao,

Nanjing Institute of Geography

and Limnology (CAS), China

Marja Tiirola,

University of Jyväskylä, Finland

${ }^{*}$ Correspondence: Stefan Bertilsson stebe@ebc.uu.se

Specialty section:

This article was submitted to

Aquatic Microbiology,

a section of the journal

Frontiers in Microbiology

Received: 20 September 2016

Accepted: 19 January 2017

Published: 03 February 2017

Citation:

Samad MS and Bertilsson S (2017)

Seasonal Variation in Abundance and Diversity of Bacterial

Methanotrophs in Five Temperate Lakes. Front. Microbiol. 8:142. doi: 10.3389/fmicb.2017.00142

\section{Seasonal Variation in Abundance and Diversity of Bacterial Methanotrophs in Five Temperate Lakes}

\author{
Md Sainur Samad ${ }^{1,2}$ and Stefan Bertilsson ${ }^{1 *}$ \\ ${ }^{1}$ Department of Ecology and Genetics, Limnology and Science for Life Laboratory, Uppsala University, Uppsala, Sweden, \\ ${ }^{2}$ Department of Microbiology and Immunology, University of Otago, Dunedin, New Zealand
}

Lakes are significant sources of methane $\left(\mathrm{CH}_{4}\right)$ to the atmosphere. Within these systems, methanotrophs consume $\mathrm{CH}_{4}$ and act as a potential biofilter mitigating the emission of this potent greenhouse gas. However, it is still not well understood how spatial and temporal variation in environmental parameters influence the abundance, diversity, and community structure of methanotrophs in lakes. To address this gap in knowledge, we collected water samples from three depths (surface, middle, and bottom) representing oxic to suboxic or anoxic zones of five different Swedish lakes in winter (ice-covered) and summer. Methanotroph abundance was determined by quantitative real time polymerase chain reaction and a comparison to environmental variables showed that temperature, season as well as depth, phosphate concentration, dissolved oxygen, and $\mathrm{CH}_{4}$ explained the observed variation in methanotroph abundance. Due to minimal differences in methane concentrations $(0.19$ and $0.29 \mu \mathrm{M}$ for summer and winter, respectively), only a weak and even negative correlation was observed between $\mathrm{CH}_{4}$ and methanotrophs, which was possibly due to usage of $\mathrm{CH}_{4}$. Methanotrophs were present at concentrations ranging from $10^{5}$ to $10^{6}$ copies/l throughout the oxic (surface) and suboxic/anoxic (bottom) water mass of the lakes, but always contributed less than $1.3 \%$ to the total microbial community. Relative methanotroph abundance was significantly higher in winter than in summer and consistently increased with depth in the lakes. Phylogenetic analysis of pmoA genes in two clone libraries from two of the ice-covered lakes (Ekoln and Ramsen) separated the methanotrophs into five distinct clusters of Methylobacter sp. (Type I). Terminal restriction fragment length polymorphism analysis of the pmoA gene further revealed significant differences in methanotrophic communities between lakes as well as between winter and summer while there were no significant differences between water layers. The study provides new insights into diversity, abundance, community composition and spatial as well as temporal distribution of freshwater methanotrophs in low-methane dimictic lakes.

Keywords: methanotrophs, methane, pmoA, qPCR, T-RFLP, lakes, ice cover

\section{INTRODUCTION}

Methane $\left(\mathrm{CH}_{4}\right)$ is a greenhouse gas which has a Global Warming Potential (GWP) 30 times higher than carbon dioxide $\left(\mathrm{CO}_{2}\right)$ and it is also the second most important greenhouse gas after carbon dioxide (IPCC, 2013). $\mathrm{CH}_{4}$ production rates are known to depend on temperature, availability of organic matter, and absence of oxygen. The largest source of natural $\mathrm{CH}_{4}$ emission 
is from natural wetlands, which contributes $170 \mathrm{Tg} /$ year (United States Environmental Protection Agency [USEPA], 2010). Freshwater lakes emit $5 \mathrm{Tg}$ to the annual $\mathrm{CH}_{4}$ annually (Hanson and Hanson, 1996). The concentration of $\mathrm{CH}_{4}$ in lakes can vary dramatically. Juutinen et al. (2009) surveyed 207 Finnish lakes and reported surface and bottom water average methane concentrations of 1 and $20.6 \mu \mathrm{M}$, respectively, while the concentrations were $<2.3 \mu \mathrm{M}$ in $75 \%$ of the lakes. Bastviken et al. (2004) also reported surface water $\mathrm{CH}_{4}$ concentrations in summer of 11 North American lakes and 13 Swedish lakes, ranging from 0.27 to $2.32 \mu \mathrm{M}$ and 0.08 to $1.89 \mu \mathrm{M}$, respectively. A resent study (Denfeld et al., 2016) also explored seven icecovered Swedish lakes and measured $\mathrm{CH}_{4}$ concentrations in surface water samples which were in the range of $0.04-1.11 \mu \mathrm{M}$. Estimating $\mathrm{CH}_{4}$ emissions from lakes and reservoirs is difficult, since there are at least four emission pathways (ebullition, diffusive flux, storage flux, and flux through aquatic vegetation; Bastviken et al., 2004). The major part of $\mathrm{CH}_{4}$ that reaches the upper mixed zone of the water body is from diffusive flux and ebullition (Bastviken et al., 2004; Walter et al., 2007).

Methanotrophs is a functional guild of microorganisms that utilize $\mathrm{CH}_{4}$ as their sole carbon and energy source (Hanson and Hanson, 1996). They are found in a wide range of habitats (e.g., lakes, rivers, streams, oceans, ponds, sediments, mud, swamps, rice paddies, meadow soils, deciduous woods, sewage sludge, and several other environments; Hanson and Hanson, 1996; Trotsenko and Khmelenina, 2002) including humic (Taipale et al., 2009) and hypersaline lakes (Carini et al., 2005) and can grow at temperatures as low as $4^{\circ} \mathrm{C}$ (Bowman et al., 1997) or as high as $72^{\circ} \mathrm{C}$ (Bodrossy et al., 1999). Aerobic methanotrophs are historically classified into three major groups: Type I (Methylobacter, Methylomonas, Methylosoma, Methylomicrobium, Methylothermus, Methylohalobius, Methylosarcina, Methylosphaera), Type II (Methylosinus, Methylocystis, Methylocella, Methylocapsa), and Type X (Methylococcus, Methylocaldum), based on a combination of morphological characteristics, intracytoplasmic membrane structures, carbon assimilation pathways, ability to fix nitrogen, and some other physiological traits (Jiang et al., 2010; Park and Lee, 2013). In lakes, methanotrophs (Type I and Type II) are widely distributed in water and sediments (Costello and Lidstrom, 1999; Sundh et al., 2005; He et al., 2012; Osudar et al., 2016). It has been reported that the diversity of methanotrophs in lakes is greater than that found in peat or marine environments (Costello and Lidstrom, 1999). To date most of the studies of methanotrophs have focused on lake sediments as this functional guild is highly abundant in such systems $\left(10^{4}\right.$ to $10^{7}$ copies of pmoA per gram of dry sediment; Yang et al., 2016). Information about methanotroph abundance (via quantitative polymerase chain reaction, qPCR) in lake water columns is still scarce, but their presence has been demonstrated by several different methods: metagenome sequencing (Peura et al., 2015), proteomics (Ullrich et al., 2016), fluorescence in situ hybridization (Eller et al., 2005), and enrichment cultures (Lidstrom and Somers, 1984; He et al., 2012).

Oxidation of $\mathrm{CH}_{4}$ to methanol is the first enzymatic step in methanotroph metabolism. This process is catalyzed by the enzyme $\mathrm{CH}_{4}$ monooxygenase (MMO). There are two forms of MMO: a cytoplasmic version or soluble MMO (sMMO), and a membrane-bound version or particulate MMO (pMMO; Murrell et al., 2000). Almost all characterized methanotrophs feature either exclusively pMMO or both PMMO and sMMO. Members of the Methylocella genus are thus far the only methanotrophs where pMMO has not been detected (Dumont and Murrell, 2005). After transforming $\mathrm{CH}_{4}$ to methanol by the MMO, the methanol is oxidized to formaldehyde by a pyrroloquinoline quinone-dependent methanol dehydrogenase (Anthony and Dales, 1996; Jiang et al., 2010). At the level of formaldehyde, carbon is assimilated by either the ribulose monophosphate pathway (RuMP) or the serine pathway, depending on the organism (Hanson and Hanson, 1996; Jiang et al., 2010; Strong et al., 2015). Alternatively, formaldehyde can be oxidized completely to carbon dioxide, which creates reducing equivalents for cellular metabolism (Dumont and Murrell, 2005). Type I methanotrophs use the RuMP pathway, whereas Type II use the serine pathway. Type X methanotrophs use both pathways (mainly RuMP; Lieberman and Rosenzweig, 2004; Jiang et al., 2010; Park and Lee, 2013).

The $p m o A$ gene encodes for a subunit of pMMO and it has been extensively used as a group-specific biomarker in molecular ecology studies of methanotrophs. This gene is present in all known methanotrophs with the exception of Methylocella and Methyloferula (Dedysh et al., 2000; Vorobev et al., 2011). There is a large database of $p m o A$ gene sequences available from characterized methanotroph strains, which makes it easy to identify a methanotroph based on its $p m o A$ gene sequence. There are a several PCR primers that can target $p m o A$ with varying specificity (Dumont and Murrell, 2005). For example, the A198F/A682R primer set targets the pmoA gene and also the amoA gene in autotrophic ammonia oxidizers (Holmes et al., 1995). One often used pmoA-specific primer set is A189F/mb661R (Costello and Lidstrom, 1999). Because of its high specificity, it is possible to use these primers to quantify the abundance of methanotrophs using qPCR. This primer set is widely used in qPCR for quantitative study of methanotrophs (Shrestha et al., 2010; Xu et al., 2013).

Methanotrophs play a crucial role in controlling global warming as well as the global methane cycle (Conrad, 1996; Hanson and Hanson, 1996). Methane is mainly produced in anoxic sediments, wetlands, and waterlogged soils, and is subsequently utilized by methanotrophs during passage to the atmosphere. Hence, methanotrophs act as a biofilter for methane release to the atmosphere. These organisms may thus reduce the contribution of methane emissions to global warming (Hanson and Hanson, 1996; Park et al., 2002). However, it is still not well understood how environmental variables control or regulate the abundance, diversity, and community compositions of methanotrophs over spatial and temporal scales. The objectives of the present study were therefore: (1) to identify potential methanotroph hotspots in five Swedish lakes; (2) to describe how environmental variables are coupled to methanotroph abundance; and (3) to assess whether the methanotroph community vary over depth, between lakes and between seasons. 


\section{MATERIALS AND METHODS}

\section{Study Sites and Sampling}

Sampling was carried out in 2012 from five temperate lakes experiencing dimictic thermal stratification: Ekoln $\left(59^{\circ} 46^{\prime} \mathrm{N}\right.$, $\left.17^{\circ} 37^{\prime} \mathrm{E}\right)$, Erken $\left(59^{\circ} 50^{\prime} \mathrm{N}, 18^{\circ} 35^{\prime} \mathrm{E}\right)$, Långsjön $\left(60^{\circ} 01^{\prime} \mathrm{N}\right.$, $\left.17^{\circ} 34^{\prime} \mathrm{E}\right)$, Siggeforasjön $\left(59^{\circ} 58^{\prime} \mathrm{N}, 17^{\circ} 09^{\prime} \mathrm{E}\right)$, and Ramsen $\left(59^{\circ} 49^{\prime} \mathrm{N}, 17^{\circ} 54^{\prime} \mathrm{E}\right)$. Samples were collected from three different depth layers of the water column: surface ( $1 \mathrm{~m}$ depth below the surface: the epilimnion zone), middle (the metalimnion zone or middle depth), and bottom [immediately above $(\sim 1 \mathrm{~m})$ sediment-water interfaces: the hypolimnion] of the lakes. The five lakes were all located in the eastern part of south-central Sweden (Supplementary Figure S1) and vary in size and trophic state (Table 1).

Sampling was carried out during winter and summer. Water was collected on March 9 and July 6 from Ekoln, March 14 and July 16 from Erken, March 14 and July 9 from Långsjön, March 16 and July 4 from Siggeforasjön, and March 20 and July 2 from Ramsen. For the winter sampling, all lakes were covered by ice and an ice drill was used to make holes for collection of water samples. Surface, middle, and bottom water samples were collected from sampling depths using a Ruttner water sampler (1 L and $2 \mathrm{~L}$ ).

\section{Temperature, Oxygen, and Sampling Depths}

On each sampling occasion, vertical temperature and oxygen concentration profiles were recorded at $1 \mathrm{~m}$ intervals using an Oxi 340i (WTW) probe.

\section{$\mathrm{CH}_{4}$ Concentrations}

For $\mathrm{CH}_{4}$ samples, a rubber tube was connected to the Ruttner sampler, facilitating the transfer of water from the sampler into $125 \mathrm{ml}$ infusion bottles without introducing air bubbles. Bottles were flushed with at least 2 volumes of water. Two $\mathrm{NaOH}$ pellets were then added to each bottle as a preservative. Red rubber stoppers with previously inserted needles $(0.6 \mathrm{~mm} \times 24 \mathrm{~mm})$ were used to get rid of excess water from the head space of bottles and then needles were removed and bottles were subsequently sealed with $20 \mathrm{~mm}$ crimp seals. Samples were stored in an inverted upright position and kept at $4^{\circ} \mathrm{C}$ until analysis.

TABLE 1 | Lake characteristics.

\begin{tabular}{|c|c|c|c|c|}
\hline & $\begin{array}{l}\text { Trophic } \\
\text { state }\end{array}$ & $\begin{array}{l}\text { Lake area } \\
\qquad\left(\mathrm{km}^{2}\right)\end{array}$ & $\begin{array}{l}\text { Maximum } \\
\text { depth }(m)\end{array}$ & Reference \\
\hline Ekoln & Eutrophic & 20 & 40 & $\begin{array}{l}\text { Eiler and Bertilsson, } \\
2004\end{array}$ \\
\hline Erken & Mesotrophic & 24 & 21 & Elliott et al., 2007 \\
\hline Långsjön & Oligotrophic & 2.5 & 12.5 & Quevedo et al., 2009 \\
\hline Siggeforasjön & Mesotrophic & 0.76 & 11 & Lindström, 1998 \\
\hline Ramsen & Mesotrophic & 0.394 & 11.5 & Hallgren et al., 1977 \\
\hline
\end{tabular}

Samples were equilibrated to room temperature $\left(20^{\circ} \mathrm{C}\right)$ prior to analysis by gas chromatography (GC) using an Agilent 7890A. The GC was calibrated with a dilution series of $\mathrm{CH}_{4}$ gas using a flame ionization detector. For sample analysis, a headspace was introduced by replacing 20 or $40 \mathrm{ml}$ of the liquid with pure nitrogen gas while the bottle was placed upside-down in a three-finger clamp attached to a ring stand. Two replicates were analyzed for each water sample.

\section{Total Bacterial Abundance}

Flow cytometry was used to estimate total bacterial abundance. Samples were preserved by adding borax-buffered and filter sterilized formaldehyde to $2 \%$ final concentration. For flow cytometry, $200 \mu \mathrm{l}$ of each preserved sample was stained with $20 \mu \mathrm{l}$ of $5 \mathrm{mM}$ Syto 13 (Invitrogen ${ }^{\circledR}$ ) for $10 \mathrm{~min}$ (del Giorgio et al., 1996). Cells were counted using a flow cytometer (Cyflow Space, Partec). Two replicates were analyzed for each sample.

\section{Water Characteristics}

Dissolved organic carbon (DOC), pH, total phosphorous (TP), total dissolved phosphorus (TDP), dissolved organic matter absorbance, water color, and chlorophyll-a, were measured in surface, middle, and bottom water samples. Water was passed over $0.2 \mu \mathrm{m}$ membrane filters (Pall Corp.) for analysis of DOC, TDP, $\mathrm{PO}_{4}{ }^{3-}, \mathrm{SO}_{4}{ }^{2-}$, water absorbance, and water color. Unfiltered water was used for analysis of TP. $\mathrm{pH}$ was measured immediately ( $1-3 \mathrm{~h})$ after bringing samples to the laboratory using a pH meter (Philips PW 9420) with BlueLine electrode (SCHOTT Instruments). DOC was measured using a total organic carbon analyzer (TOC-5000, Shimadzu). Inorganic carbon was removed by acidification (final concentration of $\mathrm{HCl}$ was $0.01 \mathrm{M}$ ) and bubbling. Samples were oxidized to carbon dioxide $\left(\mathrm{CO}_{2}\right)$ by high temperature catalytic combustion followed by IR-detection. Samples $(6 \mathrm{ml}$ each) were filled in acid washed-glass test tubes (provided) and $50 \mu \mathrm{l} 1.2 \mathrm{M} \mathrm{HCl}$ was added to each sample and mixed by gentle vortexing. Known amount of potassium phosphate was used for calibration. TP and TDP were analyzed as previously described by Menzel and Corwin (1965). Phosphate $\left(\mathrm{PO}_{4}{ }^{3-}\right)$ analysis was followed by Murphy and Riley $(1962,1968)$. Sulfate $\left(\mathrm{SO}_{4}{ }^{2-}\right)$ ion was determined with ion chromatography (883 Basic IC plusMetrohm). Absorbance scans (200 $\mathrm{nm}$ to $600 \mathrm{~nm}$ ) were performed in a $5 \mathrm{~cm}$ quartz cuvette and measured in a Lambda 40 spectrophotometer (PerkinElmer). Water color was then derived from the absorbance reading at $436 \mathrm{~nm}$ as described in Broberg (2003). For chlorophyll- $a$, cells from 0.51 of water were retained by filtration onto glass fiber filters (GF/F; Whatman). Filters were immediately frozen at $-20^{\circ} \mathrm{C}$ until analysis and duplicates were separately extracted in $95 \%$ ethanol and measured in a spectrophotometer (Hitachi U-2000) as described by Jespersen and Christoffersen (1987).

\section{DNA Extraction}

Between 300 and $500 \mathrm{ml}$ of water was filtered through sterile $0.2 \mu \mathrm{m}$ Supor membrane filters (Pall Corp.). Cells retained on filters were subsequently frozen at $-80^{\circ} \mathrm{C}$ until DNA extraction using the PowerSoil ${ }^{\circledR}$ DNA Isolation Kit (MoBio, Carlsbad, CA, 
USA). Prior to extraction, each membrane was cut into small pieces with a pair of scissors and then added to the PowerSoil ${ }^{\circledR}$ Bead Tube. The extraction protocol was then followed as detailed in the instruction manual provided by the manufacturer. After DNA extraction, all samples were analyzed with $1 \%$ agarose gel electrophoresis to verify the quality of the extracted DNA. In addition, a picogreen assay was used to quantify extracted DNA (Quant-it ${ }^{\text {TM }}$ PicoGreen dsDNA Reagent Kit, Invitrogen) using an Ultra 384 fluorometer (Tecan) as recommended by the manufacturer.

\section{Polymerase Chain Reaction Amplification, Cloning, and Sequencing}

The extracted DNA (mean $14 \mathrm{ng} / \mu \mathrm{l}$ ) was used as template in PCR with pmoA primers A189F and mb661R (Costello and Lidstrom, 1999). This primer pair capture most groups of aerobic methaneoxidizing bacteria without amplification of equally abundant amoA genes (Bourne et al., 2001). PCR amplifications (for pmoA) were done in $20 \mu \mathrm{l}$ reactions in $0.2 \mathrm{ml}$ tubes using a thermal cycler (BioER). Each PCR mixture contained $2 \mathrm{mM} \mathrm{MgCl}_{2}$, $1 \times$ PCR buffer (Invitrogen), $0.2 \mathrm{mM}$ dNTPs, $0.25 \mu \mathrm{M}$ each of the forward and reverse primers (A189F/mb661R), 4\% bovine serum albumin (New England Biolabs, USA), 0.05 units of Taq DNA Polymerase-Recombinant (Invitrogen), and 10-fold diluted DNA. All PCR reactions were performed along with one negative control containing DNase/RNase free water instead of DNA template. A thermocycling program with an initial denaturation step at $94^{\circ} \mathrm{C}$ for $3 \mathrm{~min}$ followed by 40 cycles of $94^{\circ} \mathrm{C}$ for $1 \mathrm{~min}$, $55^{\circ} \mathrm{C}$ for $1 \mathrm{~min}$ and $72^{\circ} \mathrm{C}$ for $1 \mathrm{~min}$, and a final extension at $72^{\circ} \mathrm{C}$ for $5 \mathrm{~min}$ was used. Primers used for PCR amplifications of pmoA, clone libraries and qPCR are listed in Supplementary Table S1. After amplification, 1\% agarose gel electrophoresis was performed to verify correct amplification and size of the gene by comparison to a TrackIt 100 bp DNA Ladder (Invitrogen) (Supplementary Figure S2).

PCR products generated from DNA extracted from the bottom layer of two lakes (Ekoln and Ramsen), were cloned using the TOPO TA Cloning kit (Invitrogen) as previously described (Eiler and Bertilsson, 2004). Sanger sequencing was carried out at the Uppsala Genome Center using an ABI3730XL DNA Analyzer (Applied Biosystems). All nucleotide sequences were deposited at the National Center for Biotechnology Information (NCBI) under accession numbers KC588447-KC588466. A phylogenetic tree was constructed with Mega 5 using the maximum likelihood approach and Jukes-Cantor model. The topologies of the phylogenetic tree were calculated by bootstrap analysis with 1000 replications.

\section{qPCR Analysis}

To determine the abundance of methanotrophs, qPCR was carried out using a Chromo 4 System (BIO-RAD). The $20 \mu \mathrm{l}$ reactions contained $10 \mu \mathrm{l}$ of $2 \times$ Master mix (KAPA SYBR ${ }^{\circledR}$ FAST qPCR Master Mix Universal), $200 \mathrm{nM}$ of each primer, $1 \mu \mathrm{l}$ of DNA template, and DNase/RNase free water to a final volume of $20 \mu \mathrm{l}$. For each sample, reactions were carried out in duplicate whereas linearized plasmid standards were analyzed in triplicate.

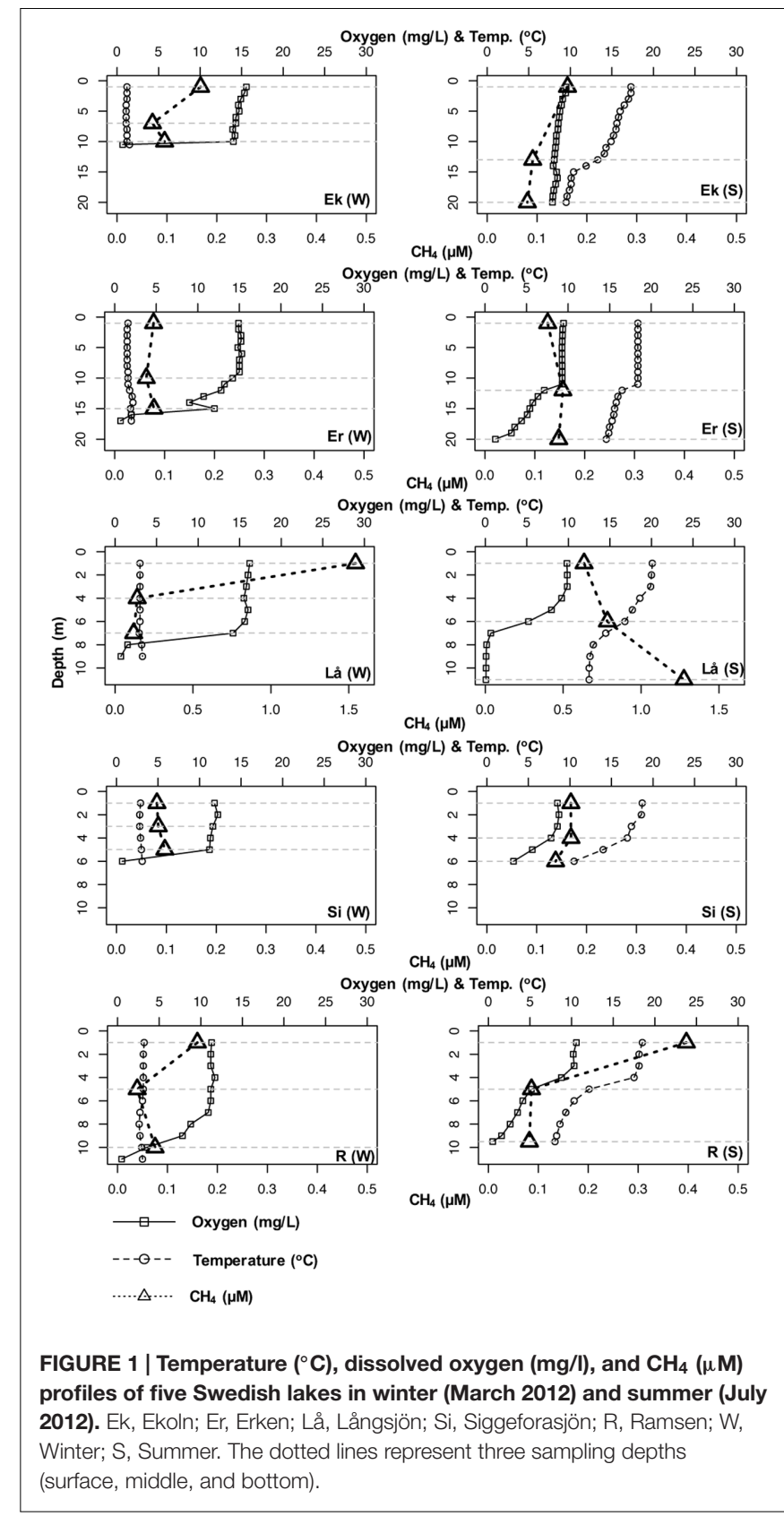

Three step cycling protocols were followed with an initial $3 \mathrm{~min}$ denaturation at $95^{\circ} \mathrm{C}$ followed by 40 cycles of denaturation at $95^{\circ} \mathrm{C}$ for $3 \mathrm{~s}$, annealing at $60^{\circ} \mathrm{C}$ for $30 \mathrm{~s}$, and extension at $72^{\circ} \mathrm{C}$ for $30 \mathrm{~s}$. Fluorescence data was acquired at $72^{\circ} \mathrm{C}$ after completing each consecutive cycle. After 40 cycles, melting curve analysis was performed by raising the temperature from 55 to $95^{\circ} \mathrm{C}$ and reading the fluorescence $10 \mathrm{~s}$ after every $0.5^{\circ} \mathrm{C}$ increase in temperature. A 10 -fold dilution series of known copies of linearized plasmid (pCR4-TOPO, Invitrogen) containing a single copy of pmoA gene (GenBank accession number KC588448) was used as a standard curve. The mean qPCR efficiency and dissociation/melting temperature $\left(T_{\mathrm{m}}\right)$ were determined to $105 \%$ and $85^{\circ} \mathrm{C}$, respectively. The coefficient of determination $\left(R^{2}\right)$ was 
TABLE 2 | Physico-chemical characteristics of the five study lakes for the two sampling occasions (winter and summer).

\begin{tabular}{|c|c|c|c|c|c|c|c|c|c|c|}
\hline Lake & Depth & $\mathrm{pH}$ & $\mathrm{DOC}(\mathrm{mg} / \mathrm{L})$ & Color (mg Pt/L) & Chl-a ( $\mu \mathrm{g} / \mathrm{L})$ & $\mathrm{TP}(\mu \mathrm{g} / \mathrm{L})$ & TDP ( $\mu \mathrm{g} / \mathrm{L})$ & $\mathrm{PO}_{4}^{3-}(\mu \mathrm{g} / \mathrm{L})$ & $\mathrm{CH}_{4}(\mu \mathrm{M})$ & $\mathrm{SO}^{2-}(\mathrm{mg} / \mathrm{L})$ \\
\hline \multirow[t]{3}{*}{ Ekoln (Winter) } & $S$ & 7.8 & 10.5 & 66 & 2 & ND & 41 & 28 & 0.17 & 30.11 \\
\hline & $\mathrm{M}$ & 7.8 & 11.7 & 63 & 2 & ND & 35 & 27 & 0.07 & 31.91 \\
\hline & $B$ & 7.8 & 11.6 & 67 & 1 & ND & 33 & 24 & 0.09 & 33.69 \\
\hline \multirow[t]{3}{*}{ Ekoln (Summer) } & S & 8.2 & 15.2 & 65 & 24 & 26 & 8 & 5 & 0.16 & 30.11 \\
\hline & $\mathrm{M}$ & 7.9 & 14.5 & 63 & 6.5 & 26 & 13 & 5 & 0.09 & 29.74 \\
\hline & $\mathrm{B}$ & 7.8 & 14 & 65 & 3.1 & 35 & 21 & 18 & 0.08 & 29.72 \\
\hline \multirow[t]{3}{*}{ Erken (Winter) } & S & 8 & 6.4 & 14 & 3.5 & ND & 42 & 36 & 0.08 & 26.42 \\
\hline & $M$ & 8.1 & 9.4 & 16 & 2 & ND & 50 & 44 & 0.06 & 40.16 \\
\hline & $\mathrm{B}$ & 7.7 & 8.7 & 17 & ND & ND & 51 & 41 & 0.08 & 35.32 \\
\hline \multirow[t]{3}{*}{ Erken (Summer) } & S & 8.4 & 10.9 & 16 & 9.3 & 28 & 7 & 2 & 0.13 & 29.20 \\
\hline & M & 8.1 & 10.9 & 17 & 4.8 & 22 & 18 & 10 & 0.16 & 28.40 \\
\hline & $\mathrm{B}$ & 7.7 & 11.5 & 18 & 3.4 & 59 & 43 & 38 & 0.15 & 27.63 \\
\hline \multirow[t]{3}{*}{ Långsjön (Winter) } & S & 8 & 3.7 & 8 & 7 & ND & 6 & 17 & 1.53 & 67.17 \\
\hline & M & 8.1 & 3.8 & 6 & 8.4 & ND & 8 & 53 & 0.14 & 68.11 \\
\hline & $\mathrm{B}$ & 7.8 & 3.4 & 6 & 7.6 & ND & 3 & 0 & 0.12 & 93.76 \\
\hline \multirow[t]{3}{*}{ Långsjön (Summer) } & $S$ & 8.6 & 7.4 & 8 & 4.8 & 16 & 0 & 3 & 0.64 & 71.02 \\
\hline & $M$ & 8.2 & 6.8 & 7 & 3.4 & 14 & 1 & 3 & 0.79 & 71.94 \\
\hline & $\mathrm{B}$ & 7.8 & 5.9 & 7 & 2 & 19 & 5 & 6 & 1.28 & 68.25 \\
\hline \multirow[t]{3}{*}{ Siggeforasjön (Winter) } & S & 6.4 & 18.9 & 137 & 0.6 & ND & 4 & 3 & 0.08 & 6.25 \\
\hline & M & 6 & 17.4 & 140 & 1.4 & ND & 3 & 4 & 0.08 & 4.04 \\
\hline & $\mathrm{B}$ & 6 & 19.9 & 139 & 0 & ND & 1 & 4 & 0.10 & 5.41 \\
\hline \multirow[t]{3}{*}{ Siggeforasjön (Summer) } & $S$ & 7.1 & 18.9 & 129 & 7.9 & 15 & 3 & 6 & 0.17 & 5.05 \\
\hline & $\mathrm{M}$ & 6.9 & 19.7 & 134 & 1.1 & 9 & 5 & 3 & 0.17 & 5.23 \\
\hline & $\mathrm{B}$ & 6.5 & 18.2 & 127 & 1.1 & 17 & 3 & 2 & 0.14 & 5.32 \\
\hline \multirow[t]{3}{*}{ Ramsen (Winter) } & $S$ & 7.7 & 13.1 & 46 & 9.8 & ND & 6 & 4 & 0.16 & 11.16 \\
\hline & $\mathrm{M}$ & 7.8 & 11.2 & 48 & 3.4 & ND & 8 & 8 & 0.04 & 9.52 \\
\hline & $\mathrm{B}$ & 7.4 & 14.9 & 54 & 0.3 & ND & 16 & 15 & 0.07 & 14.73 \\
\hline \multirow[t]{3}{*}{ Ramsen (Summer) } & S & 7.9 & 16.4 & 49 & 8.4 & 25 & 8 & 2 & 0.40 & 10.85 \\
\hline & $\mathrm{M}$ & 7.4 & 15.3 & 50 & 3.4 & 13 & 7 & 0 & 0.09 & 10.96 \\
\hline & $\mathrm{B}$ & 7.3 & 16.1 & 53 & 1.4 & 23 & 13 & 3 & 0.08 & 11.43 \\
\hline
\end{tabular}

S, Surface; M, Middle; B, Bottom; DOC, dissolved organic carbon; Chl-a, chlorophyll-a; TDP, total dissolved phosphate; TP, total phosphate; ND, Not determined.

0.98 . We assumed that each methanotrophs contained a single copy of the pmoA gene. The methanotrophs abundance was calculated as gene copy numbers per liter of water conservatively assuming 100\% DNA extraction efficiency and the relative methanotrophs abundance was estimated by comparing with flow cytometry based estimates of total microbial abundance. The relative methanotroph abundance data were used for statistical analyses.

\section{T-RFLP Analysis}

Terminal-restriction fragment length polymorphism (T-RFLP) analysis was performed on all extracted DNA samples. Fluorescently labeled gene fragments were generated by PCR using the mb661R primer with a hexachloro-6carboxyfluorescein (A189-HEX) label. PCR conditions were the same as above. After PCR amplification, amplicons were purified using the QIAquick PCR purification kit (QIAGEN) and then loaded on the agarose gel to select for the expected amplicon fragment sizes and remove primer dimers (Supplementary Figure S2). DNA bands ( $p m o A$ amplicons) were excised from the gel and then gel-purified using the QIAquick gel extraction kit (QIAGEN). Quantification was subsequently carried out with the picogreen assay as described above. For each T-RFLP analysis, $40 \mathrm{ng}$ of DNA was digested with $4 \mathrm{U}$ of the restriction enzyme MseI (New England Biolabs) for $16 \mathrm{~h}$ at $37^{\circ} \mathrm{C}$ according to the manufacturer's instructions. After heat inactivation at $65^{\circ} \mathrm{C}$ for $20 \mathrm{~min}$, all samples were stored at $-20^{\circ} \mathrm{C}$. Duplicates for each sample were sent to the Uppsala Genome Center for size separation by capillary electrophoresis using an ABI3730XL DNA Analyzer (Applied Biosystems) run in Genescan mode. The T-RFLP data were processed with GeneMarker V 2.20 (SoftGenetics). Terminal restriction fragments (T-RFs) between 50 and $500 \mathrm{bp}$ in size were considered in the subsequent analysis. $T$-RFs differing $\leq 0.5 \mathrm{bp}$ were considered to be the same fragment. Relative peak area was used as a measure of abundance and a $0.5 \%$ cut-off value was used as a baseline threshold.

\section{PLS Model and Statistics}

Partial least squares regression (PLS) was used to relate and predict the relative methanotroph abundance to an extensive set of environmental parameters using XLSTAT. Data were square root transformed prior to the PLS 
analysis. In PLS, the model quality indices were reported as $\mathrm{Q}^{2}$ (cum), $\mathrm{R}^{2} \mathrm{Y}$ (cum) and $\mathrm{R}^{2} \mathrm{X}$ (cum) parameters. The $\mathrm{Q}^{2}$ (cum) index represents the global contribution of the components and identify the most stable model (maximum $=1$ ). The $\mathrm{R}^{2} \mathrm{Y}$ (cum) and $\mathrm{R}^{2} \mathrm{X}$ (cum) represent the explanatory power of the components for the dependent variable and explanatory variables, respectively. The beta/standardized coefficient test was performed to understand which of the independent variables have greater effect on the dependent variable (methanotrophs). In addition, a goodness of fit statistics was performed to fit the model. In a PLS plot, variables are strongly correlated when they appear on the perimeter of the circle. For positive correlations, variables appear close to each other and for negative correlation, variables appear far from one another. Analysis of variance (ANOVA) was performed to test for significant differences in methanotroph abundance between winter and summer and between water depths (surface, middle, and bottom) as well as interactive effects. For T-RFLP data, a permutational multivariate analysis of variance (PERMANOVA) test (permutations $=1000$ ) was performed in R using "vegan" package (Oksanen et al., 2013) along with Bray-Curtis distance matrix to identify significant differences in methanotrophic community composition by seasons, lakes, and depths.

\section{RESULTS}

\section{Environmental Conditions}

All lakes were ice covered during the winter sampling and all had developed a distinct thermocline during the summer sampling. Except for Siggeforasjön which was moderately acidic $(\mathrm{pH}<7)$, the lakes were slightly alkaline $(\mathrm{pH}>7)$. For all lakes, dissolved oxygen concentration dropped down to $<1.3(\mathrm{mg} / \mathrm{l})$ at the largest depths (Figure 1) except for summer samples of Ekoln $(7.85 \mathrm{mg} / \mathrm{l})$ and Siggeforasjön $(3.22 \mathrm{mg} / \mathrm{l})$. The bottom samples of Ekoln (Summer) were taken at $20 \mathrm{~m}$ as the sensor cables prevented us from sampling further down. $\mathrm{CH}_{4}$ concentration varied only slightly over depth and between seasons within each lake (Figure 1). The highest concentration of $\mathrm{CH}_{4}$ was detected in Långsjön during both seasons; surface samples in winter $(1.53 \mu \mathrm{M})$ and bottom samples in summer $(1.28 \mu \mathrm{M})$. Figure 1 and Table 2 summarize the physico-chemical properties of the five studied lakes in winter (March) and summer (July).

\section{Total Bacterial Abundance and Methanotrophs in Lakes}

Except for lake Ekoln, bacterial abundance was typically more than twofold higher in summer samples than in winter (Figure 2A). The highest number of bacteria was
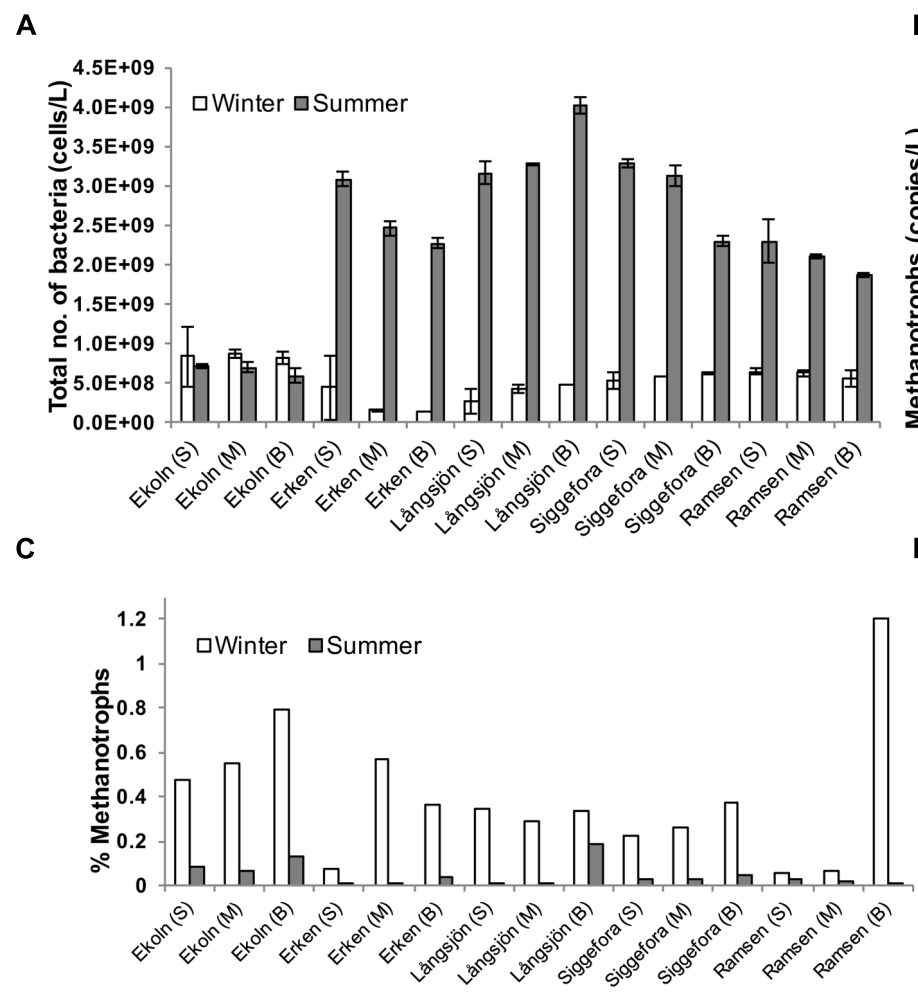

B

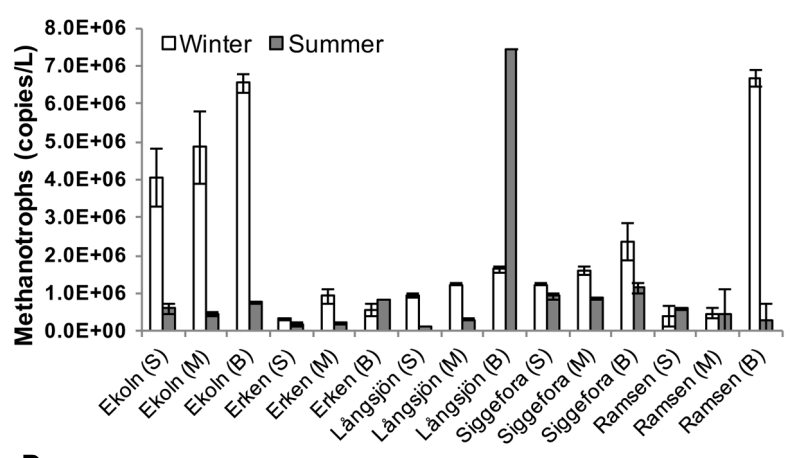

D

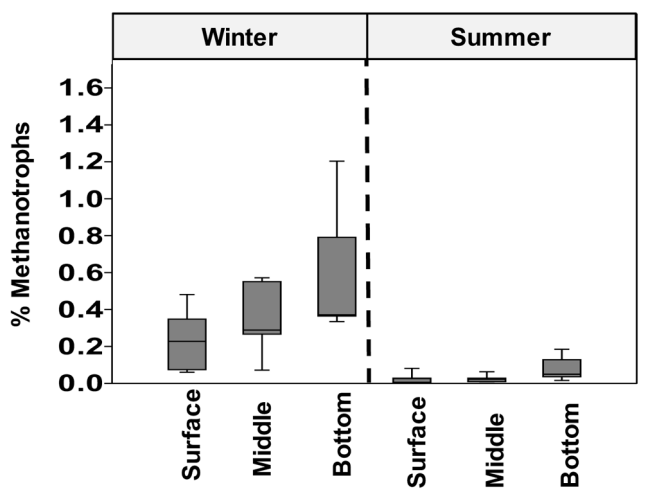

FIGURE 2 | Bacterial and methanotroph abundance. Bacterial (A) and methanotroph abundance (B) in five Swedish lakes in winter and summer. Ratio (\%) of methanotrophs is compared to total bacterial abundance (C). (D) Box plot showing percent of methanotrophs in surface (S), middle (M), and bottom (B) waters from the five studied lakes in winter and summer. 
observed in bottom samples from the summer sample of lake Långsjön at $4.0( \pm 0.1) \times 10^{9}$ cells/l while the lowest bacterial abundance was observed in Erken winter samples at 2.5 $( \pm 1.7) \times 10^{8}$ cells/l.

Methanotroph abundance detected by qPCR as $p m o A$ gene copies ranged from $10^{5}$ to $10^{6} / 1$ (Figure 2B). The highest abundance of methanotrophs was observed in summer samples of deep water from lake Långsjön at $7.4 \times 10^{6} \pm 1.6 \times 10^{4}$ (mean \pm SD) pmoA gene copies/l and for deep lake Ramsen winter samples at $6.7 \times 10^{6} \pm 2.2 \times 10^{5}$. The lowest number of methanotrophs was observed in winter samples from lake Erken at $6 \times 10^{5} \pm 8.4 \times 10^{4}$ gene copies/l. All winter samples from Ekoln showed high methanotroph concentrations. The ratio between methanotrophs and total number of bacteria was less than $1.3 \%$ for both seasons and was always higher in winter when compared to the corresponding summer samples (Figure 2C). On average, the bottom samples also featured higher methanotroph contribution $(0.35 \%)$, compared to the middle $(0.2 \%)$ and surface $(0.13 \%)$ samples (Figure 2D), but the ANOVA only identified the seasonality effect as significant (ANOVA $F=24.81, p<0.001$ ) while the effect of water layer was weaker $(F=3.27$, $p=0.055)$.

\section{Relationships between Environment Parameters and Methanotrophs}

In the PLS model, the relative abundance of methanotrophs was mainly explained by component 1 (67\%) and to a lesser extent by component 2 (5\%). The first component (Comp1) was calculated with the $\mathrm{Q}^{2}$ (cum), $\mathrm{R}^{2} \mathrm{Y}$ (cum), and $\mathrm{R}^{2} \mathrm{X}$ (cum) parameters of 0.59 , 0.67 , and 0.27 , respectively and the second component (Comp2) was calculated with the $\mathrm{Q}^{2}$ (cum), $\mathrm{R}^{2} \mathrm{Y}$ (cum), and $\mathrm{R}^{2} \mathrm{X}$ (cum) parameters of $0.49,0.72$, and 0.41 , respectively (Supplementary Figure S3). The quality of components assessed through cross validation showed that only component $1\left(\mathrm{Q}^{2}=0.59\right)$ was significant $\left(\mathrm{Q}^{2}\right.$ limit $>0.097$, corresponding to $\left.p<0.05\right)$. The relative methanotroph abundance was positively correlated with winter season $(r=0.76)$, bottom layer $(r=0.32)$, phosphate $(r=0.47)$, TDP $(r=0.4)$, dissolved oxygen $(r=0.33), \mathrm{SO}_{4}{ }^{2-}$ $(r=0.14)$ and color $(r=0.07)$; and negatively correlated with summer season $(r=-0.76)$, temperature $(r=-0.78)$, chlorophyll- $a(r=-0.41)$, surface layer $(r=-0.23), \mathrm{CH}_{4}$ $(r=-0.16)$, DOC $(r=-0.15), \mathrm{pH}(r=-0.14)$, and middle layer $(r=-0.1)$ (Figure 3A). The VIPs (Variable Importance for the Projection) for each explanatory variable of both components (Comp1 and Comp2) showed that temperature, season, and
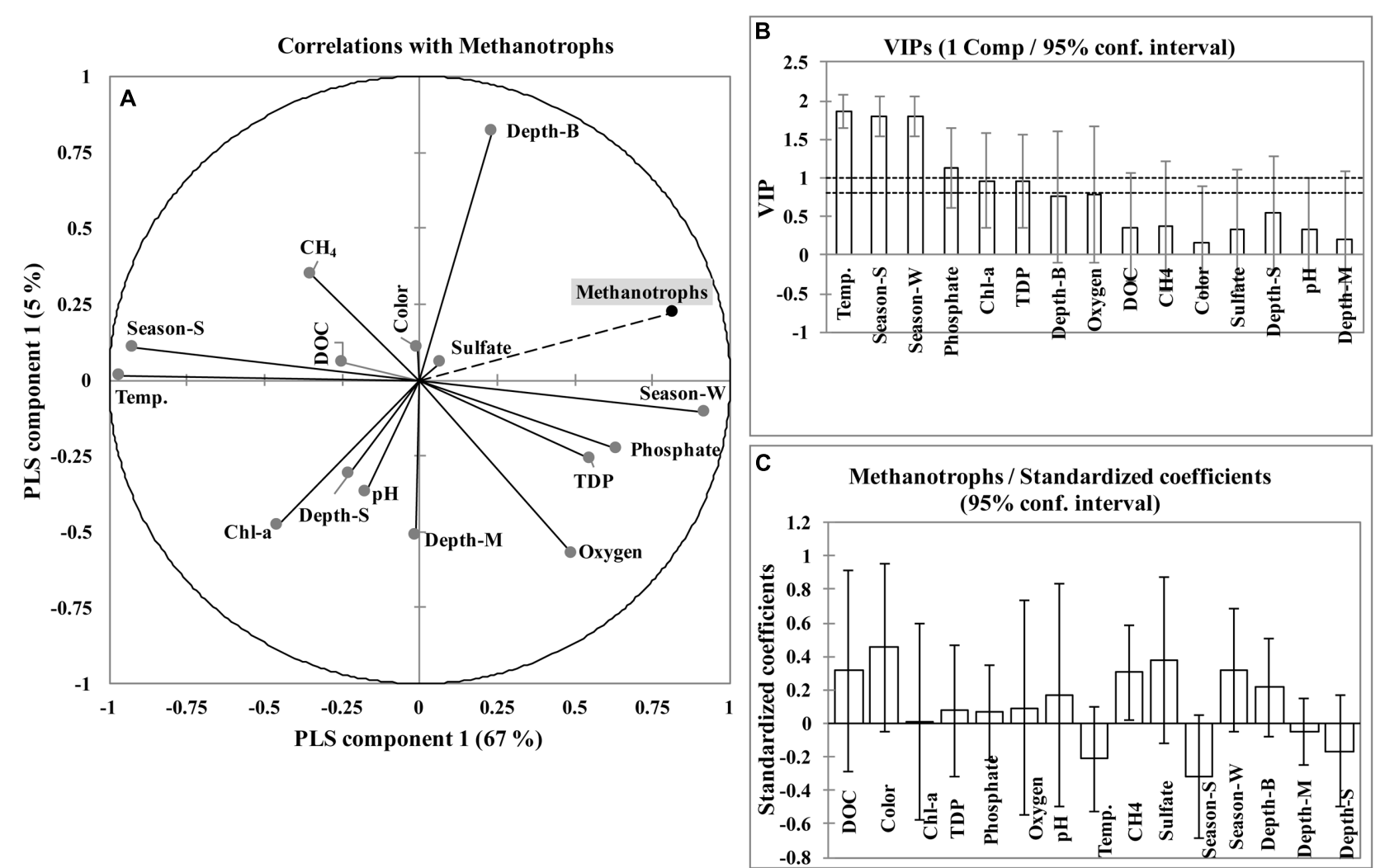

FIGURE 3 | Correlation circle of partial least squares (PLS) regression, illustrating the correlations of the variables with the first two axes (associated to the first two components) (A). The VIPs (Variable Importance for the Projection) for each explanatory variables of first component (B). Standardized/beta coefficient test from PLS model and variables are not significant when confidence interval around the standardized coefficient include 0 (C). Season-W, winter season; Season-S, summer season; DOC, dissolved organic carbon; TDP, total dissolved phosphorous; Chl-a, chlorophyll-a; Depth-S, depth (surface); Depth-M, depth (middle); Depth-B, depth (bottom). 


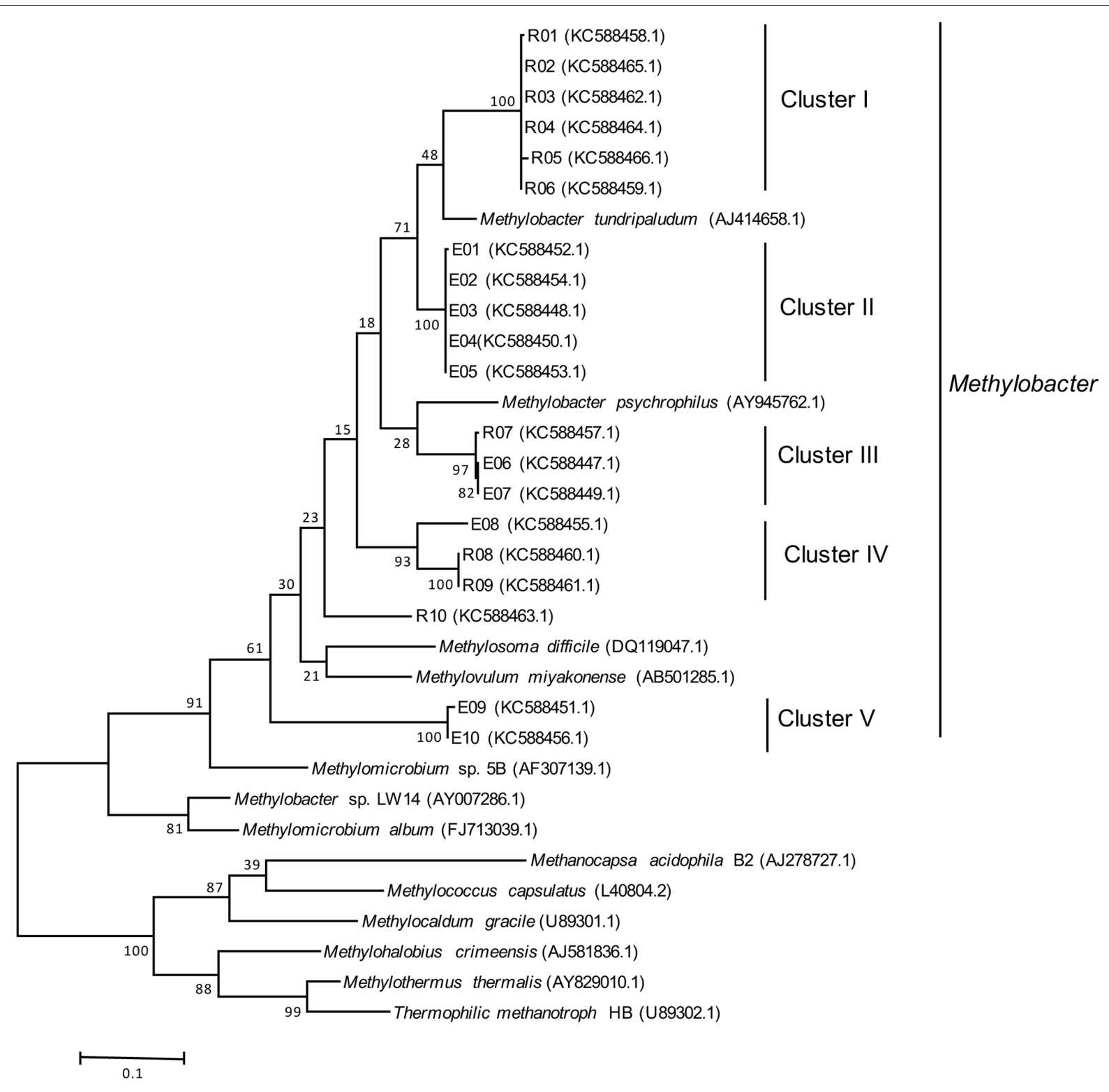

FIGURE 4 | Maximum likelihood phylogenetic tree of pmoA gene sequences (508 bp) amplified by A189F/mb661R from two clone libraries (10 clones from Ekoln and $\mathbf{1 0}$ clones from Ramsen). Number of bootstrap replications is 1000.

phosphate contributed the most to the model (VIP > 1 ; Figures 3B and Supplementary Figure S4). In the PLS model, the standardized coefficient test was done to identify important predictor(s). Only $\mathrm{CH}_{4}$ was significant $(p<0.05)$ as the coefficient was different from 0 (Figure 3C). Goodness of fit statistics showed that methanotroph abundance was accurately predicted by the model $\left(\mathrm{R}^{2}=0.808, \mathrm{SD}= \pm 0.126\right)$.

\section{pmoA Clone Libraries and Phylogenetic Analysis}

Two separate clone libraries were generated from the $p m o A$ gene fragments amplified from DNA of the bottom water samples of Ekoln and Ramsen. From each lake, the inserts from 10 randomly selected clones were sequenced, confirming the presence of methanotrophs in the lakes (Figure 4). All sequences obtained were affiliated with Methylobacter, and overall grouped into five phylogenetic clusters (clusters I-V, Figure 4). Six clones from Ramsen (R01-R06) grouped in cluster I while two clusters were unique for Ekoln; cluster II (E01-E05) and cluster V (E09, E10). Cluster III (R07, E06, E07) and cluster IV (E08, R08, R09) were mixed clones from both Ekoln and Ramsen.

\section{Methanotroph Community Characterization}

T-RFLP data were analyzed to detect differences in methanotroph community composition between lakes, seasons, and depth 


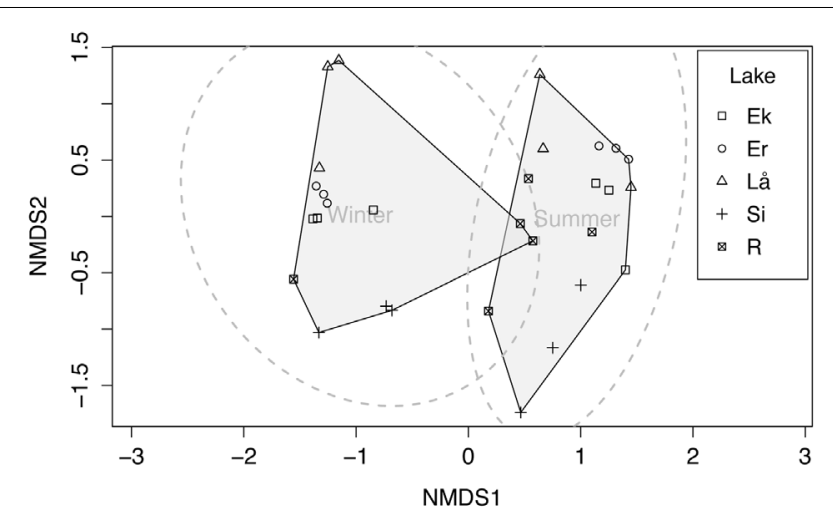

FIGURE 5 | Two dimensional non-metric multidimensional scaling (NMDS) plot of methanotrophic bacterial terminal restriction fragments (T-RFs) at three depths and two seasons (winter and summer) of five Swedish lakes in winter and summer. The stress value = 0.153. Ek, Ekoln; Er, Erken; Lå, Långsjön; Si, Siggeforasjön; R, Ramsen. Circles (gray dotted line) represent 95\% confidence interval and shaded regions represent winter and summer samples.

layers. The non-metric multidimensional scaling (NMDS) plot based on Bray-Curtis indices clearly identified two community types (winter and summer) at 95\% confidence interval (Figure 5). In general, summer samples seemed to be more diverse than winter samples (i.e., more T-RFs), and especially summer samples (surface) of Erken and Långsjön showed $>75$ unique T-RFs (Supplementary Figure S5). Adonis test (PERMANOVA) showed that lakes $(F=2.922, p<0.01)$, seasons $(F=8.45$, $p<0.001)$, and interaction between lakes and seasons $(F=2.66, p<0.01)$ had a significant effect on community composition.

\section{DISCUSSION}

\section{Methanotrophs and $\mathrm{CH}_{4}$ in Lakes}

Methanotrophs were present in all the studied lakes regardless of depth (surface, middle, and bottom), season (winter and summer), trophic status (Eutrophic: Ekoln; Mesotrophic: Erken, Siggeforasjön, Ramsen; and Oligotrophic: Långsjön) as well as lake water chemistry. This suggests that methanotrophs are ubiquitous and an integral part of the lake ecosystem. $\mathrm{CH}_{4}$ is by definition a critical resource for methanotrophs. The average $\mathrm{CH}_{4}$ concentration of our studied lakes were 0.19 and $0.29 \mu \mathrm{M}$ for summer and winter, respectively. Similar concentrations were previously observed in 13 Swedish lakes and seven ice-covered Swedish lakes where surface $\mathrm{CH}_{4}$ concentrations ranged from 0.08 to $1.9 \mu \mathrm{M}$ (Bastviken et al., 2004) and 0.04 to $1.11 \mu \mathrm{M}$, respectively (Denfeld et al., 2016). Although, the bottom water $\mathrm{CH}_{4}$ concentrations were much lower in our lakes compared to previously reported Finish lakes, where the average $\mathrm{CH}_{4}$ concentration was $20.6 \mu \mathrm{M}$ (Juutinen et al., 2009).
Among the lakes, the bottom layer of Långsjön was identified as a potential "hot spot" for both $\mathrm{CH}_{4}$ and methanotrophs. This lake surprisingly had among the lowest DOC $(5.2 \mathrm{mg} / \mathrm{l})$ and highest $\mathrm{SO}_{4}{ }^{2-}$ concentrations (67-94 mg/l) compared to the others and our results are thus in agreement with a previous study suggesting that surface $\mathrm{CH}_{4}$ and DOC are inversely correlated (Bastviken et al., 2004). This particular lake is groundwater fed and drain a catchment dominated by soils of marine origin (Denfeld et al., 2016) and also featured lower oxygen levels at the bottom compared to the other studied lakes, likely creating conditions conducive for $\mathrm{CH}_{4}$ production. However, a recent microcosm study (Denfeld et al., 2016) performed in the laboratory under variable $\mathrm{CH}_{4}$ concentrations $(1,10,100$, $500 \mu \mathrm{M})$ and constructing temperatures $\left(2,4,10,20^{\circ} \mathrm{C}\right)$ could not demonstrate any significant $\mathrm{CH}_{4}$ oxidation in surface waters from this lake. The probable causes of this observation could be interference from other controlling factors such as the presence of alternative electron acceptors (e.g., $\mathrm{SO}_{4}{ }^{2-}, \mathrm{NO}_{3}{ }^{-}$, etc.) or spatial patchiness of resident methanotroph communities.

\section{Environmental Control of Methanotrophs}

The relative methanotroph abundance was significantly higher in winter than in summer for all lakes (Figure 2C) while total bacterial abundance was higher in summer than in winter (Figure 2A). This implies that the lower temperatures in winter combined with other prevailing conditions such as minimal inputs of phytoplankton-derived organic substrates is a conducive environment for methanotrophs while other bacteria are less competitive. This agrees with previous studies reporting that the largest methanotroph biomass and activity in lakes occurred at low temperature (Sundh et al., 2005). In our study, methanotrophs were detected throughout the water columns and at higher abundances at the bottom of the lakes, suggesting that methanotrophs are widely distributed in temperate lakes and that they preferentially grow in sub-oxic conditions.

$\mathrm{CH}_{4}$ is known to be an important regulator that affects methanotroph abundance. $\mathrm{CH}_{4}$ was found to be a significant variable, but showed a weak and inverse correlation $(r=-0.16)$ with relative methanotroph abundance. This suggests that methanotrophs utilized $\mathrm{CH}_{4}$ as their energy source and hence methanotrophs proliferated while depleting $\mathrm{CH}_{4}$ from the water column.

Oxygen is also a critically important factor controlling the growth and abundance of aerobic methanotrophs. For surface waters, we observed higher dissolved oxygen in winter and this was associated with a higher representation of methanotrophs in the community. This is in agreement with earlier studies showing that plant root systems provide high amounts of oxygen to the rhizosphere (van der Nat and Middelburg, 1998; Popp et al., 2000) enhancing the growth, abundance, and activity of methanotrophs (Yun et al., 2012). Additionally, the availability of free $\mathrm{PO}_{4}{ }^{3-}$ appeared to be strongly coupled to methanotroph abundance. Similar observations were reported by Denfeld et al. (2016) who suggested that a shortage of labile phosphorus may hamper methanotrophs by invoking stronger competition with other bacterial groups with higher affinity for this critical nutrient. 


\section{Identity and Community Structure of Methanotrophs}

The sequence analysis of 20 randomly selected pmoA clones from bottom winter samples of two lakes (Ekoln and Ramsen) revealed a significant representation of five clusters of Methylobacter affiliated with Type I methanotrophs of class gammaproteobacteria. This represents one out of 14 genera of methanotrophs (Jiang et al., 2010). Similar results have also been observed in other studied temperate lakes where Type I methanotrophs dominated (Sundh et al., 2005; Denfeld et al., 2016; Ricão Canelhas et al., 2016).

The diversity of methanotrophs and their spatial and temporal distribution patterns and dynamics are not well understood in temperate lakes. Our T-RFLP results revealed two distinct clusters of methanotrophic communities in temperate lakes, suggesting seasonal turnover of this microbial guild. We observed comparatively higher numbers of T-RFs in summer samples, suggesting a more evenly composed methanotroph community under such conditions. Methanotrophs were nevertheless highly abundant in winter, but the extended period of low-temperature and assumed limited dynamic shifts in the planktonic food webs during winter seem to have favored a few populations able to cope with and profit from such conditions. Low predation in winter may have played a role in this regard and could potentially open up for expansion of particularly competitive methanotroph populations, such as some previously identified Type I methanotrophs (Henckel et al., 2001). Our results also indicate significant differences of methanotrophic communities across lakes of different trophic status while there were no significant differences in methanotroph community composition between the different depth layers in the respective lake, implying either significant vertical scrambling of the communities or wide local niches with regards to oxygen, temperature, and water chemistry.

In conclusion, we uncovered a dynamic distribution of methanotroph communities between lakes, both with regards to abundance and predominant populations and communities. $\mathrm{CH}_{4}$ concentrations were overall low in the studied lake ecosystems

\section{REFERENCES}

Anthony, C., and Dales, S. L. (1996). "The biochemistry of methanol dehydrogenase," in Microbial Growth on C1 Compounds, eds M. E. Lidstrom and F. R. Tabita (Dordrecht: Kluwer Academic Publishers), 213-219.

Bastviken, D., Cole, J., Pace, M., and Tranvik, L. (2004). Methane emissions from lakes: dependence of lake characteristics, two regional assessments, and a global estimate. Global Biogeochem. 18, 1-12. doi: 10.1029/2004GB002238

Bodrossy, L., Kovács, K. L., McDonald, I. R., and Murrell, J. C. (1999). A novel thermophilic methane-oxidising $\gamma$-Proteobacterium. FEMS Microbiol. Lett. 170, 335-341. doi: 10.1111/j.1574-6968.1999.tb13392.x

Bourne, D. G., Donald, I. A. N. R. M. C., and Murrell, J. C. (2001). Comparison of pmoA PCR primer sets as tools for investigating methanotroph diversity in three danish soils. Appl. Environ. Microbiol. 67, 3802-3809. doi: 10.1128/AEM. 67.9.3802

Bowman, J. P., McCammon, S. A., and Skerratt, J. H. (1997). Methylosphaera hansonii gen. nov., sp. nov., a psychrophilic, group I methanotroph from and was inversely correlated with methanotroph abundance likely due to $\mathrm{CH}_{4}$ being depleted by the methanotrophs.

\section{AUTHOR CONTRIBUTIONS}

MSS and SB designed the project. MSS carried out the field work and laboratory analyses with assistance and advice from SB. MSS analyzed the data and drafted the manuscript. A final version of the MSS was then prepared by MSS and SB.

\section{FUNDING}

The study was funded by the Swedish Research Council Formas and The Swedish Research Council.

\section{ACKNOWLEDGMENTS}

This work is based on an MSc thesis carried out by MSS under the supervision of SB. The original thesis is published online according to the policy of the Department where the degree project was carried out (Samad, 2012). We would like to thank Alexander Eiler, Sebastian Sobek, Eva S. Lindström, Silke Langenheder, Omneya Ahmed, and all other members of the Limnology group at the Department of Ecology and Genetics, Uppsala University for helpful suggestions. We thank Dandan Shen for her joint efforts in sampling and water chemistry analysis. We also thank Monica Ricão Canelhas for her technical support with Flow cytometry and Elias Broman for his assistance in GIS (Supplementary Figure S1). Thanks to Jan Johansson, Torsten Jeske, and Peter Brodelius for sampling assistance.

\section{SUPPLEMENTARY MATERIAL}

The Supplementary Material for this article can be found online at: http://journal.frontiersin.org/article/10.3389/fmicb. 2017.00142/full\#supplementary-material

Antarctic marine-salinity, meromictic lakes. Microbiology 143, 1451-1459. doi: 10.1099/00221287-143-4-1451

Broberg, A. (2003). Water and Sediment Analyses, 4th Edn. Uppsala: Uppsala University.

Carini, S., Bano, N., LeCleir, G., and Joye, S. B. (2005). Aerobic methane oxidation and methanotroph community composition during seasonal stratification in Mono Lake, California (USA). Environ. Microbiol. 7, 1127-1138. doi: 10.1111/j. 1462-2920.2005.00786.x

Conrad, R. (1996). Soil microorganisms as controllers of atmospheric trace gases $\left(\mathrm{H}_{2}, \mathrm{CO}, \mathrm{CH}_{4}, \mathrm{OCS}, \mathrm{N}_{2} \mathrm{O}\right.$, and $\left.\mathrm{NO}\right)$. Microbiol. Mol. Biol. Rev. 60, 609-640.

Costello, A. M., and Lidstrom, M. E. (1999). Molecular characterization of functional and phylogenetic genes from natural populations of methanotrophs in lake sediments. Appl. Environ. Microbiol. 65, 5066-5074.

Dedysh, S. N., Liesack, W., Khmelenina, V. N., Suzina, N. E., Trotsenko, Y. A., Semrau, J. D., et al. (2000). Methylocella palustris gen. nov., sp. nov., a new methane-oxidizing acidophilic bacterium from peat bogs, representing a novel 
subtype of serine-pathway methanotrophs. Int. J. Syst. Bacteriol. 50, 955-969. doi: 10.1099/00207713-50-3-955

del Giorgio, P. A., Bird, D. F., Prairie, Y. T., and Planas, D. (1996). Flow cytometric determination of bacterial abundance in lake plankton with the green nucleic acid stain SYTO 13. Limnol. Oceanogr. 41, 783-789. doi: 10.4319/lo.1996.41.4. 0783

Denfeld, B. A., Ricão Canelhas, M., Weyhenmeyer, G. A., Bertilsson, S., Eiler, A., and Bastviken, D. (2016). Constraints on methane oxidation in icecovered boreal lakes. J. Geophys. Res. Biogeosci. 121, 1924-1933. doi: 10.1002/ 2016JG003382

Dumont, M. G., and Murrell, J. C. (2005). Community-level analysis: key genes of aerobic methane oxidation. Methods Enzymol. 397, 413-427. doi: 10.1016/ S0076-6879(05)97025-0

Eiler, A., and Bertilsson, S. (2004). Composition of freshwater bacterial communities associated with cyanobacterial blooms in four Swedish lakes. Environ. Microbiol. 6, 1228-1243. doi: 10.1111/j.1462-2920.2004.00657.x

Eller, G., Kanel, L., and Kruger, M. (2005). Cooccurrence of aerobic and anaerobic methane oxidation in the water column of lake plu see. Appl. Environ. Microbiol. 71, 8925-8928. doi: 10.1128/AEM.71.12.8925-8928.2005

Elliott, J. A., Persson, I., Thackeraya, S. J., and Blencknerc, T. (2007). Phytoplankton modelling of Lake Erken, Sweden by linking the models PROBE and PROTECH. Ecol. Model. 202, 421-426. doi: 10.1016/j.ecolmodel.2006.11.004

Hallgren, E., Jansson, P. O., Landenmark, L., and Larsson, P. E. (1977). Limnologisk Undersökning av Sjön Ramsen I Februari-March 1977. Uppsala: Uppsala University.

Hanson, R. S., and Hanson, T. E. (1996). Methanotrophic bacteria. Microbiol. Rev. $60,439-471$.

He, R., Wooller, M. J., Pohlman, J. W., Quensen, J., Tiedje, J. M., and Leigh, M. B. (2012). Diversity of active aerobic methanotrophs along depth profiles of arctic and subarctic lake water column and sediments. ISME J. 6, 1937-1948. doi: $10.1038 /$ ismej.2012.34

Henckel, T., Udo, J., and Ralf, C. (2001). Vertical distribution of the methanotrophic community after drainage of rice field soil. FEMS Microbiol. Ecol. 34, 279-291. doi: 10.1111/j.1574-6941.2001.tb00778.x

Holmes, A. J., Costello, A. M., Lidstrom, M. E., and Murrell, J. C. (1995). Evidence that particulate methane monooxygenase and ammonia monooxygenase may be evolutionarily related. FEMS Microbiol. Lett. 132, 203-208. doi: 10.1111/j. 1574-6968.1995.tb07834.x

IPCC (2013). "Climate change 2013: the physical science basis," in Contribution of Working Group I to the Fifth Assessment Report of the Intergovernmental Panel on Climate Change, eds T. F. Stocker, D. Qin, G.-K. Plattner, M. Tignor, S. K. Allen, J. Boschung, et al. (Cambridge: Cambridge University Press), $1-1535$.

Jespersen, A. M., and Christoffersen, K. (1987). Measurement of chlorophyll-a from phytoplankton using ethanol as extraction solvent. Arch. Hydrobiol. 109, $445-454$.

Jiang, H., Chen, Y., Jiang, P. X., Zhang, C., Smith, T. J., Murrell, J. C., et al. (2010). Methanotrophs: multifunctional bacteria with promising applications in environmental bioengineering. Biochem. Eng. J. 49, 277-288. doi: 10.1016/j. bej.2010.01.003

Juutinen, S., Rantakari, M., and Kortelainen, P. (2009). Methane dynamics in different boreal lake types. Biogeosciences 5, 209-223.

Lidstrom, M. E., and Somers, L. (1984). Seasonal study of methane oxidation in lake Washington. Appl. Environ. Microbiol. 47, 1255-1260.

Lieberman, R. L., and Rosenzweig, A. C. (2004). Biological methane oxidation: regulation, biochemistry, and active site structure of particulate methane monooxygenase. Crit. Rev. Biochem. Mol. 39, 147-164. doi: 10.1080/ 10409230490475507

Lindström, E. S. (1998). Bacterioplankton community composition in a boreal forest lake. FEMS Microbiol. Ecol. 27, 163-174. doi: 10.1111/j.1574-6941.1998. tb00534.x

Menzel, D. H., and Corwin, N. (1965). The measurement of total phosphorous in seawater based on the liberation of organically bound fractions by persulfate oxidation. Limnol. Oceanogr. 10, 280-282. doi: 10.4319/lo.1965.10.2.0280

Murphy, J., and Riley, J. P. (1962). A modified single solution method for the determination of phosphate in natural waters. Anal. Chim. Acta 27, 31-36. doi: 10.1016/S0003-2670(00)88444-5
Murphy, J., and Riley, J. P. (1968). A single-solution method for the determination of phosphate in sea water. J. Mar. Biol. Ass. 37, 9-14. doi: 10.1017/ S0025315400014776

Murrell, J. C., Gilbert, B., and McDonald, I. R. (2000). Molecular biology and regulation of methane monooxygenase. Arch. Microbiol. 173, 325-332. doi: $10.1007 / \mathrm{s} 002030000158$

Oksanen, J., Blanchet, F. G., Kindt, R., Legendre, P., Minchin, P. R., O’Hara, R. B., et al. (2013). vegan: Community Ecology Package. R Package Version 2.0-10. Available at: http://CRAN.R-project.org/package=vegan

Osudar, R., Liebner, S., Alawi, M., Yang, S., Bussmann, I., and Wagner, D. (2016). Methane turnover and methanotrophic communities in arctic aquatic ecosystems of the Lena Delta, Northeast Siberia. FEMS Microbiol. Ecol. 92, fiw116. doi: 10.1093/femsec/fiw116

Park, D., and Lee, J. (2013). Biological conversion of methane to methanol. Korean J. Chem. Eng. 30, 977-987. doi: 10.1007/s11814-013-0060-5

Park, S., Brown, K. W., and Thomas, J. C. (2002). The effect of various environmental and design parameters on methane oxidation in a model biofilter. Waste Manag. Res. 20, 434-444.

Peura, S., Sinclair, L., Bertilsson, S., and Eiler, A. (2015). Metagenomic insights into strategies of aerobic and anaerobic carbon and nitrogen transformation in boreal lakes. Sci. Rep. 5, 1-6. doi: 10.1038/srep12102

Popp, T. J., Chanton, J. P., Whiting, G. J., and Grant, N. (2000). Evaluation of methane oxidation in the rhizosphere of a Carex dominated fen in north central Alberta, Canada. Biogeochemistry 51, 259-281. doi: 10.1023/A:1006452609284

Quevedo, M., Svanbäck, R., and Eklöv, P. (2009). Intrapopulation niche partitioning in a generalist predator limits food web connectivity. Ecology 90 , 2263-2274. doi: 10.1890/07-1580.1

Ricão Canelhas, M., Denfeld, B. A., Weyhenmeyer, G. A., Bastviken, D., and Bertilsson, S. (2016). Methane oxidation at the water-ice interface of an icecovered lake. Limnol. Oceanogr. 61, 1-13. doi: 10.1002/lno.10288

Samad, M. S. (2012). Environmental Control of Methanotrophic Bacteria in Temperate Lakes. MSc. thesis, in Applied Biotechnology, Uppsala University, Uppsala, 43.

Shrestha, M., Shrestha, P. M., Frenzel, P., and Conrad, R. (2010). Effect of nitrogen fertilization on methane oxidation, abundance, community structure, and gene expression of methanotrophs in the rice rhizosphere. ISME J. 4, 1545-1556. doi: 10.1038 /ismej. 2010.89

Strong, P. J., Xie, S., and Clarke, W. P. (2015). Methane as a resource: can the methanotrophs add value? Environ. Sci. Technol. 49, 4001-4018. doi: 10.1021/ es504242n

Sundh, I., Bastviken, D., and Tranvik, L. J. (2005). Abundance, activity, and community structure of pelagic methane-oxidizing bacteria in temperate lakes. Appl. Environ. Microbiol. 71, 6746-6752. doi: 10.1128/AEM.71.11.6746

Taipale, S., Jones, R. I., and Tiirola, M. (2009). Vertical diversity of bacteria in an oxygen-stratified humic lake, evaluated using DNA and phospholipid analyses. Aquat. Microbiol. Ecol. 55, 1-16. doi: 10.3354/ame01277

Trotsenko, Y. A., and Khmelenina, V. N. (2002). Biology of extremophilic and extremotolerant methanotrophs. Arch. Microbiol. 177, 123-131. doi: 10.1007/ s00203-001-0368-0

Ullrich, N., Casper, P., Otto, A., and Gessner, M. O. (2016). Proteomic evidence of methanotrophy in methane-enriched hypolimnetic lake water. Limnol. Oceanogr. 61, 1-10. doi: 10.1002/lno.10333

United States Environmental Protection Agency [USEPA] (2010). Methane, and Nitrous Oxide Emissions from Natural Sources. EPA 430-R-10-001. Washington, DC: United States Environmental Protection Agency.

van der Nat, F. J. W. A., and Middelburg, J. J. (1998). Seasonal variation in methane oxidation by the rhizosphere of Phragmites australis and Scirpus lacustris. Aquat. Bot. 61, 95-110. doi: 10.1016/S0304-3770(98)00072-2

Vorobev, A. V., Baani, M., Doronina, N. V., Brady, A. L., Liesack, W., Dunfield, P. F., et al. (2011). Methyloferula stellata gen. nov., sp. nov., an acidophilic, obligately methanotrophic bacterium possessing only a soluble methane monooxygenase. Int. J. Syst. Evol. Microbiol. 61, 2456-2463. doi: 10.1099/ijs.0. 028118-0

Walter, K. M., Smith, L. C., and Stuart Chapin, F. (2007). Methane bubbling from northern lakes: present and future contributions to the global methane budget. Philos. Trans. R. Soc. A 365, 1657-1676. doi: 10.1098/rsta.2007. 2036 
Xu, K., Tang, Y., Ren, C., Zhao, K., Wang, W., and Sun, Y. (2013). Activity, distribution, and abundance of methane-oxidizing bacteria in the near surface soils of onshore oil and gas fields. Appl. Microbiol. Biotechnol. 97, 7909-7918. doi: 10.1007/s00253-012-4500-7

Yang, Y., Zhao, Q., Cui, Y., Wang, Y., Xie, S., and Liu, Y. (2016). Spatio-temporal variation of sediment methanotrophic microorganisms in a Large Eutrophic Lake. Microbiol. Ecol. 71, 9-17. doi: 10.1007/s00248-015-0667-7

Yun, J., Zhuang, G., and Ma, A. (2012). Community structure, abundance, and activity of methanotrophs in the zoige wetland of the tibetan plateau. Microbiol. Ecol. 63, 835-843. doi: 10.1007/s00248-011-9981-x
Conflict of Interest Statement: The authors declare that the research was conducted in the absence of any commercial or financial relationships that could be construed as a potential conflict of interest.

Copyright (c) 2017 Samad and Bertilsson. This is an open-access article distributed under the terms of the Creative Commons Attribution License (CC BY). The use, distribution or reproduction in other forums is permitted, provided the original author(s) or licensor are credited and that the original publication in this journal is cited, in accordance with accepted academic practice. No use, distribution or reproduction is permitted which does not comply with these terms. 